\title{
(9)
}

\section{Determinants of Organizational Commitment among Academics of HEIs: The Buffering Role of Coworker Support}

\author{
Ashfaq Ahmad ${ }^{\text {a }}$, Hazrat Bilal ${ }^{\text {b }}$, Palwasha Bibi ${ }^{\text {c }}$ \\ ${ }^{a}$ Center for Management and Commerce, University of Swat, Pakistan \\ Email: Ashfaqahmad79@outlook.com \\ ${ }^{\mathrm{b}}$ Center for Management and Commerce, University of Swat, Pakistan \\ Email: hbilal@uswat.edu.pk \\ ${ }^{\mathrm{c}}$ Center for Management and Commerce, University of Swat, Pakistan \\ Email: dr.plawashabibi@gmail.com
}

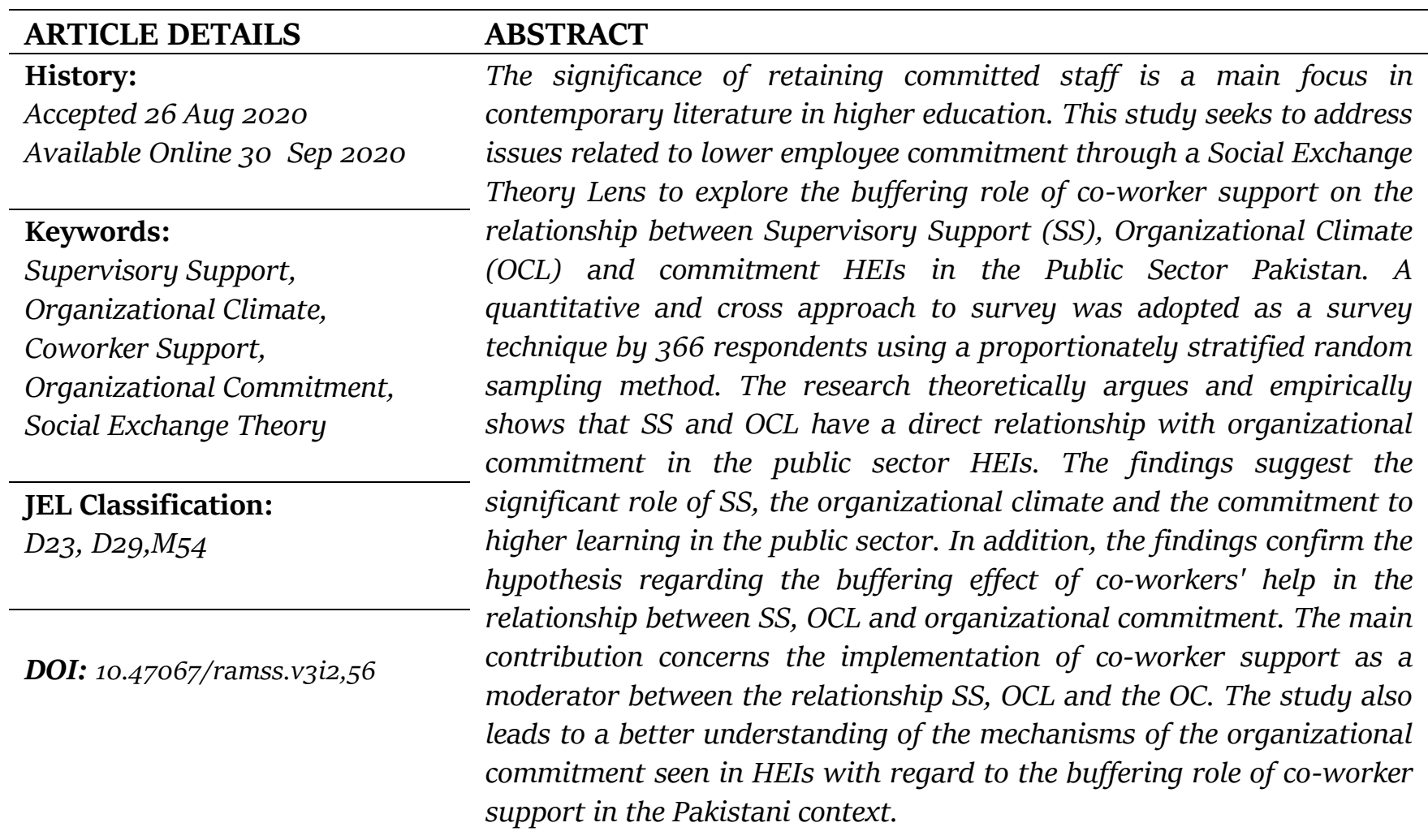

(C) 2020 The authors. Published by SPCRD Global Publishing. This is an open access article under the Creative Commons Attribution-

NonCommercial 4.0

Corresponding author's email address: hbilal@uswat.edu.pk

\section{Introduction}

The organizations operating from a resource based view require employees to perform beyond expectation to achieve a sustained competitive advantage (Abbas et al., 2015). The contemporary higher education arena is highly competitive with top management highly interested to figure out how to make 
employers more committed and loyal than ever realized before (Holtom, Mitchell, Lee, \& Eberly, 2008). Organizations are increasingly paying attention to issues that go hand in hand with organizational commitment such as lack of training and development and unconducive organizational climate. McGunnigle and Jameson, (2000) in their ground breaking paper contends training and development and good work climate are evaluated as critical factors for enhancing organizational commitment. In the same vein many have been carried out in the context of higher education system which depicts significance of organizational commitment particularly in western context (Prowse \& Prowse, 2009) while scarce treatment had been extended as evident from scant published studies on its key part in economic development of countries (Bok, 1990). Thus, it can be said that in domains of higher education, the foremost asset for its success is commitment of its academic staff as we move towards embracing the ideals of knowledge-based economy (Humphreys \& Hoque, 2007).

The higher education access in Pakistan had risen considerably in the past two decades. The greater accessibility to higher education had created opportunities for faculty mobility and student preferences. This trend is manifested in works of Abulkareem et al. (2015) who proclaims that almost 19,000 university employees switch jobs for better prospects in South Asia. Likewise, Saba, (2011) study concluded that almost $5 \%$ of the employees' exhibit lack of commitment in public sector universities of Pakistan. Earlier scholars stressed the importance of the commitment that workers who are well encouraged and dedicated perform well and remain loyal. The literature review shows that more research is required in the field of employee commitment particularly in public HEIs, in Pakistan. Thus, this study aims to probe further the relationship between SS, OCL, Coworker support, and commitment of academic staff in public sector universities in Pakistan.

It is demonstrated that education sector play major role in the development of every society. Similarly, skilled and committed employee is necessary for the success of any university. Employees who are more devoted towards an organization are anticipated to perform better. However, a review of literature demonstrates that contemporary organizations consider the concept of OCL as a major concern and an ongoing challenge (Meyer \& Parfyonova, 2010; In the light of these issues, Universities in the public sector must consider and mitigate the problem of low employee commitment. Public universities in Pakistan must, in the first place, consider the possible factors leading to a lack of commitment on the part of employees to address this issue. In general terms the factors that impact OC in the context of Pakistan have been investigated by a number of researchers. However, there is lack of consensus in terms of agreement in findings vary considerably due to variations in number of variables and context. Despite this, the issues of OCs among academics in public sector universities require more attention than ever realized before (Ahmad, Bibi \& Majid, 2017; Bibi, Ahmad, \& Majid, 2018For public sector universities, the lack of employee commitment remains a major concern. Ahmad el at, (2017) also stated that the public institutions are facing high employee's turnover and lack of commitment.

In generally terms, variables which influence OC were examined in empirical terms by researchers. However, lack of consensus stems in the findings from various studies as multiple and variety of variables have been examined in different context but amidst this there is need to uncover and investigate further (Abbas, Yousafzai \& Khattak, 2015).In addition, as a moderator, the incorporation of co-worker support would fill the theoretical void found in literature. The main contributions of this undertaking had spawned from attempt to introduce co-worker support in the form of moderating variable between SS, OCL and academic staff commitment. Earlier researchers such as Wang, Odell and Schwille, (2008); Rousseau and Aube, 2010 had examined effects of co-worker support as moderating variable to measure job stress levels. However, specifically the use of Social exchange theory to examine relations between SS, OCL and OC is conspicuous by its absence. 
Consequently, in view of literature, In previous study, there is no evidence that all these variables are studied together, especially in the context of Pakistan.. Therefore, the present study aims to fill the gap by demonstrating all these variables together to ascertain their relationship in explaining OC in Pakistan particularly in public HEIs.

\section{Literature Review}

\subsection{Organizational commitment}

Nurturing and sustaining OC is crucial for organizations, because employees are mission critical assets of a firm in accordance with resource-based view of a firm. Several researchers have defined OC in their own manner. According to Meyer and Allen, (1997), "OC refers to emotional bond of employee with organization to admit prevalent values and goals”. Kwon and Banks, (2004) contends that OC plays a significant role to germinate a spirit of motivation, reduce stress and job-hopping practices in employees. It is evident that a committed employee walks an extra mile in pursuit of organizational objectives (Bibi, Ahmad, \& Majid, 2016; Meyer et al., 1989). This idea also goes in sync with social exchange theory from domains of sociology which contends that individuals reciprocate to institutional support in the shape of OC and loyalty (Beham, 2011; Newman, 2011). Based on the preceding discussion, thus it can be said that securing committed and motivated workforce is important strategic issue for education institutes.

\subsection{Supervisor Support and Organizational commitment}

Supervisory support is a vital tool of HRM practices which effects employee commitment. The supervisory support is assessment and instruction of performance of employees regarding career management, job direction, and expansion of career network of employee (Tan, 2008). Likewise, the provision of such support is important for motivating, developing and retaining teaching faculty (Bigliardi et al, 2005). Stronger and friendly supervisor-subordinate relationship increases the degree of employee commitment to be in the company longer. (Eisenberger et al, 1990). Supervisor support is likely to enhance employee commitment. Similarly, Silbert (2005) have discussed that talented and skilled employees are very important for any organization and the effective way to retain is providing them friendly environment and supportive and friendly supervisor.

Furthermore, It is important to research the supervisory support and its impact on OC. As there is little study have been done to find out the supervisory support and its impact on employee commitment in education sector in KP, Pakistan.

Literature review also highlighted that there is controversy in the finding of previous researchers such as Chandna and Krishnan (2009) found no relationship between SS and OC. Furthermore, a researcher also proclaims that supervisor support styles differ from organization to organization due to organizational cultural differences. The previous studies also recommend that additional research is needed to examine the relationship between SS and OC in the framework of South East Asia. Mainly in public sector HEIs. Hence the first hypothesis of this study is:

Hypothesis 1: There is positive relationship between SS and OC.

\subsection{Organizational Climate and Organizational Commitment}

The concept of organizational climate has been well-defined as observations of organizational environment by the employees of any organization (Edgar and Geare, 2005). Organizational climate refer to the environment where employee perform their duties (Danish, Ramzan \& Ahmad, 2013). It is self-evident that certainly; conducive working climate encourages employees to achieve their organizational goals. Therefore, organizations should create such working climate that supports to 
enhance the employee commitment level. Mangi et al, (2011) and Moos (1994), describe work environment as the individual understands of daily work environment of the organization i.e, clean services cape and surrounding. Moreover, many other studies such as Abdullah and Ramay, (2012) Vanaki and Vagharseyyedin, (2009) also found that organizational climate had imperative and positive relationship with OC. However, extensive literature review reveals that a whopping majority of the studies on organizational climate have been undertaken in a variety of sectors with dismal attention paid on higher education especially in Pakistan.

The current study espouses employee perception of their work place surrounding thereby organizational climate was has been deliberated as independent variable here. Furthermore, the literature supports that conducive work climate is very effective for enriching employee experience and work so that they could effectively achieve organizational goals and showcase positive employee behaviors. The literature has also outlined that work environment can foster a culture of positivity that could help individuals to do more for less. Hence, based on reviewed literature on organizational climate and commitment the second hypothesis is proposed as:

Hypothesis 2: There is positive relationship between organizational climate and OC.

Having established the corresponding hypothesis for two of the elements of the study we now divert our attention towards the remaining variables in ensuing paragraphs.

\subsection{Coworker Support (Moderating Variable) and Organizational Commitment}

In HEIs, co-worker support is considered to be a vital source of OC. The term coworker's relations refer to relationship amongst employees operate at same level in the organization and communicate each other for organizational related issues (Rousseau \& Aube, 2010). Moreover, coworkers can be responsible for required support that creates encouraging and helpful working atmosphere that may lead colleague to a feeling of dedication toward organization. Therefore, employee support is necessary and plays a crucial role in OC and job-related trends. (Chiaburu \& Harrison, 2008). Similarly, in other studies of Covey (1991), Leonard and Leonard, (2003) and Senge (1990) support the idea that academics perform better when they work together. The line of reasoning so far supports notion of reciprocity as enunciated in SET theory especially when employees perceive organization caters for opportunities of $\mathrm{T} \& \mathrm{D}$, and conducive working climate as well as supportive coworkers.

Renowned scholar which include Tschannen-Moran, (2001); Knapp, (2003); Jarzabkowski, (2003); Wang, Odell and Schwille, (2008) supports positive result of academic staff coworker support. This involve a number of variables such as a positive attitude towards teaching, a decrease in work tension, work efficiency improvements, increased motivation, improved professional growth, supporting new colleagues and improving the dedication of academic staff. Therefore, the support of colleagues is necessary and plays a crucial role in OC. It therefore proposes that coworker support be a moderating variable in the connection between SP, organizational climate and OC. Theoretically, coworker support could moderate the relation between SP, organizational climate and commitment in a variety of ways. As such, the recurrent trend shows that workers who have the support of their peers are more dedicated to the organisation than those that do not have the support of peers (Rousseau \& Aubé, 2010). In order to fill this gap, the present study places coworker support as a moderating variable and purposes to further explore its effect on SP, organisational climate and OC, Hence, this research study hypothesizes as follows.

Hypothesis 3: Coworker support moderates the association between SS, and organizational commitment. 
Hypothesis 4: Coworker support moderates the association between organizational climate and OC.

\section{Methodology}

\subsection{Procedure \& Participants}

Zikmund, Babin, Carr and Griffen, (2012) contends that sample size should be representative of the entire population. This study considers Krejcie and Morgan, (1970) table in order to ensure the sample size is well enough and equivalent representative of the entire population. Based on Morgan table which suggest that for the total population 3550, the minimum sample size of 350 is adequate. Thus, the sampling technique that is utilized as part of this study is the proportionate stratified random sampling. A total 650 questionnaires were distributed to gather data from public HEIs in Khyber Pakhtunkhwa (KP), Pakistan. Proportionate stratified random sampling is most suitable method for the current study. The main intention for using this technique is to provide the equivalent representation to each university irrespective of their size and to shun sampling error (Creswell \& Poth, 2017). A total of 370 questionnaires from academic staff were collected. $80 \%$ of 370 respondents were males; $61 \%$ of the respondents were lecturers, $29 \%$ assistant professors, $7 \%$ associated professor and 3\% professor. $70 \%$ of the participants' hold Ms/M.Phil degree, $25 \%$ hold Master's degree and the only $5 \%$ of the participant hold degree of doctorate. $65 \%$ of the participants were married and $35 \%$ were single. In terms of experience, only $44.5 \%$ of the respondents spent 1-10 years working in university.

\subsection{Measurement}

Here $O C$ is operationalized as willingness of the academics to accept and agree with university values and goals (Allen \& Meyer, 1997). To assess OC nine items short version of Mowday, Steers \& Porter, (1979) was used. Supervisory support refers to the interpersonal relationship between the manager and the subordinate in the organization (Tan, 2008). An eight items of London (1993) were incorporated to assess supervisory support. Organizational climate was operationalized as prevalence of good and safe working environment for the academic staff so that the can performed their function for the betterment of the institute (Edgar \& Geare, 2005). The four items proposed by Edgar \& Geare (2005) were used to measure organizational climate. Co-worker support - coworker support is the level of support expressed among peers in an organization (Ducharme \& Martin's, 2000). In the current study, coworker support is operationalized as the assistance, help and care received by an employee from their colleagues in assigned tasks, and they operate at same level, with no formal authority of one over another. Co-worker support was incorporated with ten questions employed by Ducharme and Martin's (2000). All the questions were measured on a seven-points Likert scale, where 1 indicates strongly disagree and 7 indicates strongly agree.

\section{Results}

The analysis for the purposes of this study has been carried out with Smart PLS version 2.0 packages.

\subsection{Convergent validity}

In order to establish convergent validity in accordance with Hair et al. (2010), who have suggested the three types of estimation viz. Firstly, factor loading, secondly, average variance extraction (AVE) and lastly, composite reliability (CR). As indicated in the Table 1 all the items loading were above 0.5 which is appropriate value and acceptable as mentioned by (Hair et al., 2010). Therefore, total eight items were deleted ( $\left.\mathrm{CS}_{5}, \mathrm{CS} 6, \mathrm{CS} 7, \mathrm{CS} 8, \mathrm{CS} 9, \mathrm{CS} 10, \mathrm{SS} 8\right)$ as there loading value were below 0.5, and only 24 items were retained out of 31 items. Additionally, given Table 1 also reveals that CR for almost all constructs is greater than 0.7 as well as the AVE exceeded 0.5 threshold as suggested by Hair et al., (2010). 
Table 1. CVA (factor loading, CR and AVE of Latent variable)

\begin{tabular}{|l|l|c|l|l|}
\hline Construct & Items & Loadings & AVE & CR \\
\hline Coworker Support & 1 & 0.906 & 0.770 & 0.930 \\
\hline & 2 & 0.916 & & \\
\hline & 3 & 0.923 & & \\
\hline & 4 & 0.754 & & \\
\hline Organizational Commitment & 1 & 0.946 & 0.730 & 0.960 \\
\hline & 2 & 0.577 & & \\
\hline & 3 & 0.781 & & \\
\hline & 4 & 0.884 & & \\
\hline & 5 & 0.835 & & \\
\hline & 6 & 0.796 & & \\
\hline & 7 & 0.898 & & \\
\hline & 8 & 0.959 & & \\
\hline & 9 & 0.950 & & \\
\hline Organizational Climate & 1 & 0.905 & 0.85 & 0.958 \\
\hline & 2 & 0.901 & & \\
\hline & 3 & 0.927 & & \\
\hline Supervisor Support & 4 & 0.957 & & \\
\hline & 1 & 0.934 & 0.765 & 0.957 \\
\hline & 2 & 0.794 & & \\
\hline & 3 & 0.790 & & \\
\hline & 4 & 0.932 & & \\
\hline & 5 & 0.798 & & \\
\hline & 6 & 0.928 & & \\
\hline
\end{tabular}

\subsection{Discriminant Validity}

Discriminant validity is aimed to confirm the construct validity and explore association among latent construct, which seek to ensure that the measures which shouldn't be related was examined considering the scale Fornell and Lacker's (1981). The square root of AVE ought to exceed the variance shared among the constructs of the study as recommended by Fornell and Lacker's (1981). In the same way, cross-loading is another alternative to the treatment of discriminate validity, which is also comprehended by matching most outer loadings with cross-loadings(Hair, et al., 2013). As reported in table 2, confirming the discriminant validity of the outer model, as the diagonal values are better than the other value of the row and column in which they are placed (Hair et al, 2010).

Table 2: Square Root of AVE and Correlation

\begin{tabular}{|l|l|l|l|l|}
\hline & CS & SS & OC & OCL \\
\hline Coworker Support & $\mathbf{0 . 8 7 8}$ & & & \\
\hline Supervisor Suport & 0.011 & $\mathbf{0 . 8 7 5}$ & & \\
\hline $\begin{array}{l}\text { Organizational } \\
\text { Commitment }\end{array}$ & 0.190 & 0.237 & $\mathbf{0 . 8 5 5}$ & \\
\hline Organizational Climate & 0.227 & 0.408 & 0.142 & $\mathbf{0 . 9 2 3}$ \\
\hline
\end{tabular}


The following stage involved examining the standardized path coefficients for the purpose of testing hypothesized relationships considered in the study. Consequently, in Smart PLS applications, the bootstrapping method was used to achieve the final data. Table 3 and Figure 1 show the results of the structural model of the study..

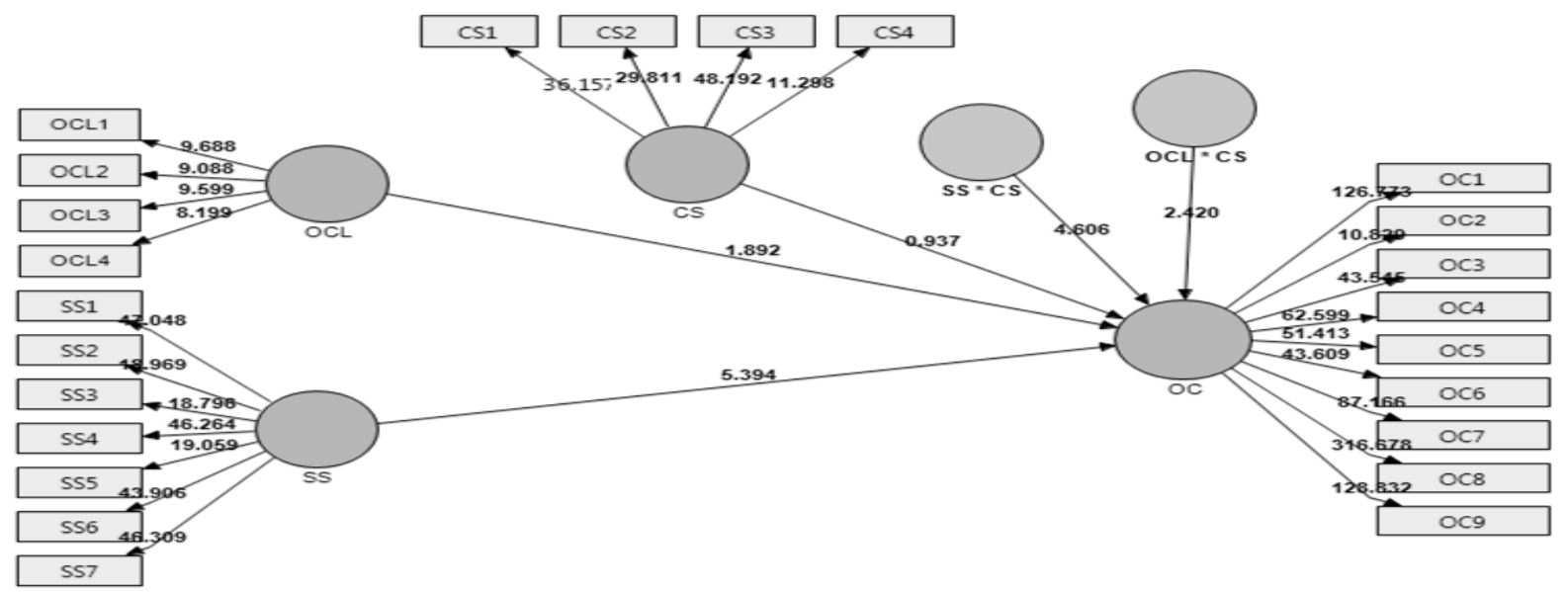

Figure 1 Structural Model with Moderator

Table 3: Structural Model

\begin{tabular}{|c|c|c|c|c|c|c|}
\hline Hypothesis & Relationship & $\begin{array}{c}\text { Beta } \\
(\beta)\end{array}$ & $\begin{array}{l}\text { Standard } \\
\text { Error }\end{array}$ & $\begin{array}{l}\text { T- } \\
\text { Statistics }\end{array}$ & $\begin{array}{l}\text { P- } \\
\text { Value }\end{array}$ & Decision \\
\hline HI & $\begin{array}{l}\text { Supervisor } \quad \text { Support } \\
\text { Organizational Commitment }\end{array}$ & 0.259 & 0.046 & $5 \cdot 394$ & 0.00 & supported \\
\hline $\mathrm{H} 2$ & $\begin{array}{l}\text { Organizational Climate } \\
\text { Organizational Commitment }\end{array}$ & 0.135 & 0.061 & 1.892 & 0.03 & supported \\
\hline H3 & $\begin{array}{l}\text { Supervisor Support * Coworke } \\
\text { Support }->\quad \text { Organizationa } \\
\text { Commitment }\end{array}$ & 0.413 & 0.108 & 4.606 & 0.00 & supported \\
\hline $\mathrm{H}_{4}$ & $\begin{array}{l}\text { Organizational } \\
\text { Coworker } \quad \text { Climate } \\
\text { Organizational Commitment }\end{array}$ & 0.247 & 0.144 & 2.420 & 0.01 & supported \\
\hline
\end{tabular}

There exists a significant relation in SS and OC as reported in above Table III, beta=0.259, $t=5.394$ and $p<0.00$. Furthermore, the outcome also presented an evidence of a positive connection between organizational climate with a beta $=0.135, t=1.892$ and $p<0.03$. In addition, this research has used a product indicator approach to analyze the buffering role of coworker support in the combination of supervisory support, organizational climate and OC (Helm, Eggert, \& Garnefeld, 2010). The outcomes of structural model displayed a support for hypothesis 3 , with $\beta=0.413, t=4.606, p$ $<0.000$ and hence found it statistically significant. Figure 2 reveals moderating effect of coworker support on the relationship between SS and OC, which suggests a positive link between SS and OC for public universities than for universities with lower co-worker support. 


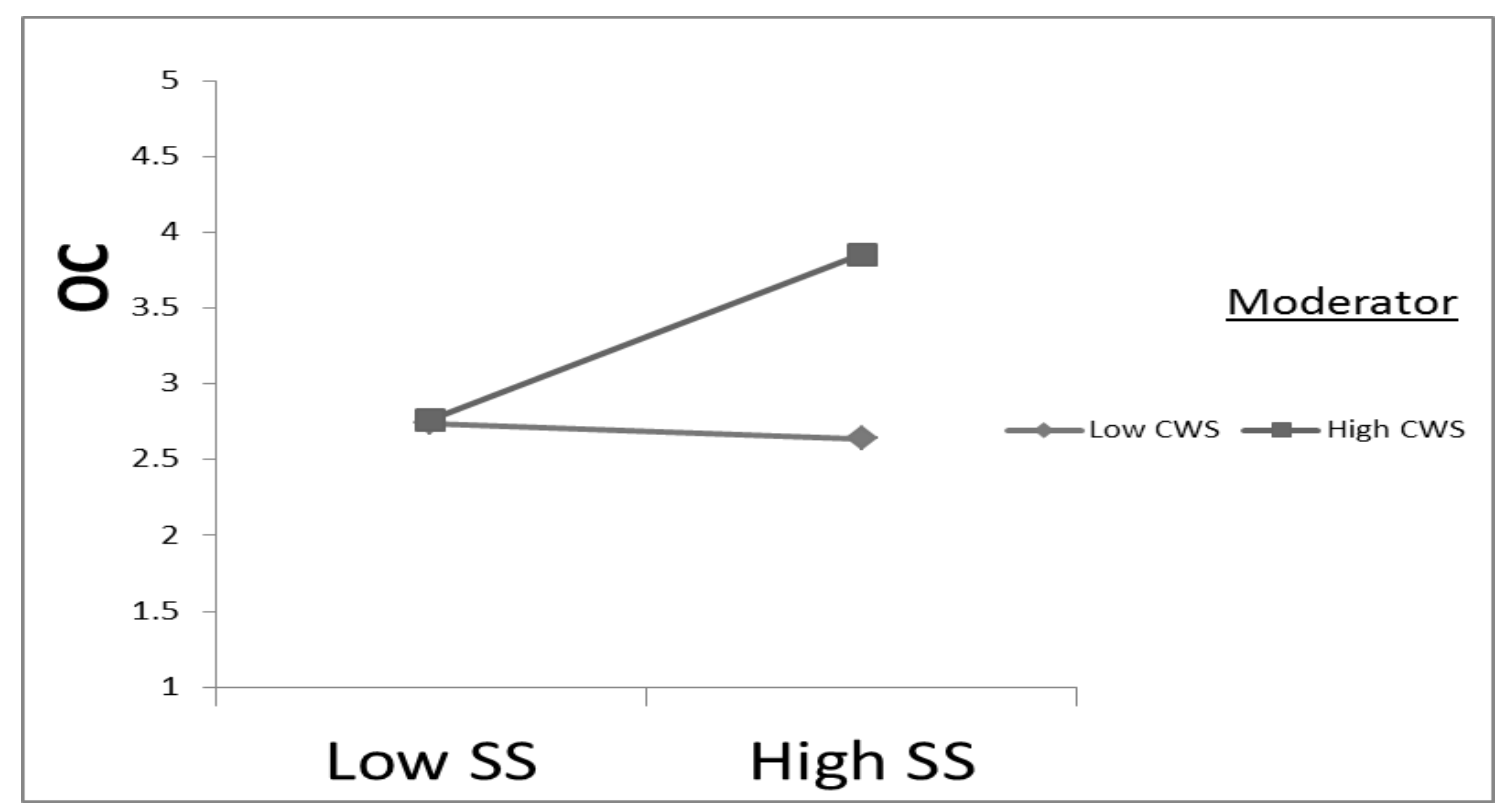

Figure 2: Interaction effect of coworker support on SS and commitment.

Similarly, Hypothesis 4 was endorsed with results of statistical significance in the structural model ( $\beta$ $=0,247, \mathrm{t}=2,420, \mathrm{p}<\mathrm{o}, 01)$. Figure 3 displays the moderating impact of coworker support on the association between the organizational climate and the OC, indicating a stronger positive relationship between the organizational climate and the OC of public universities with higher coworker support than public HEIs with comparatively lower coworker support.

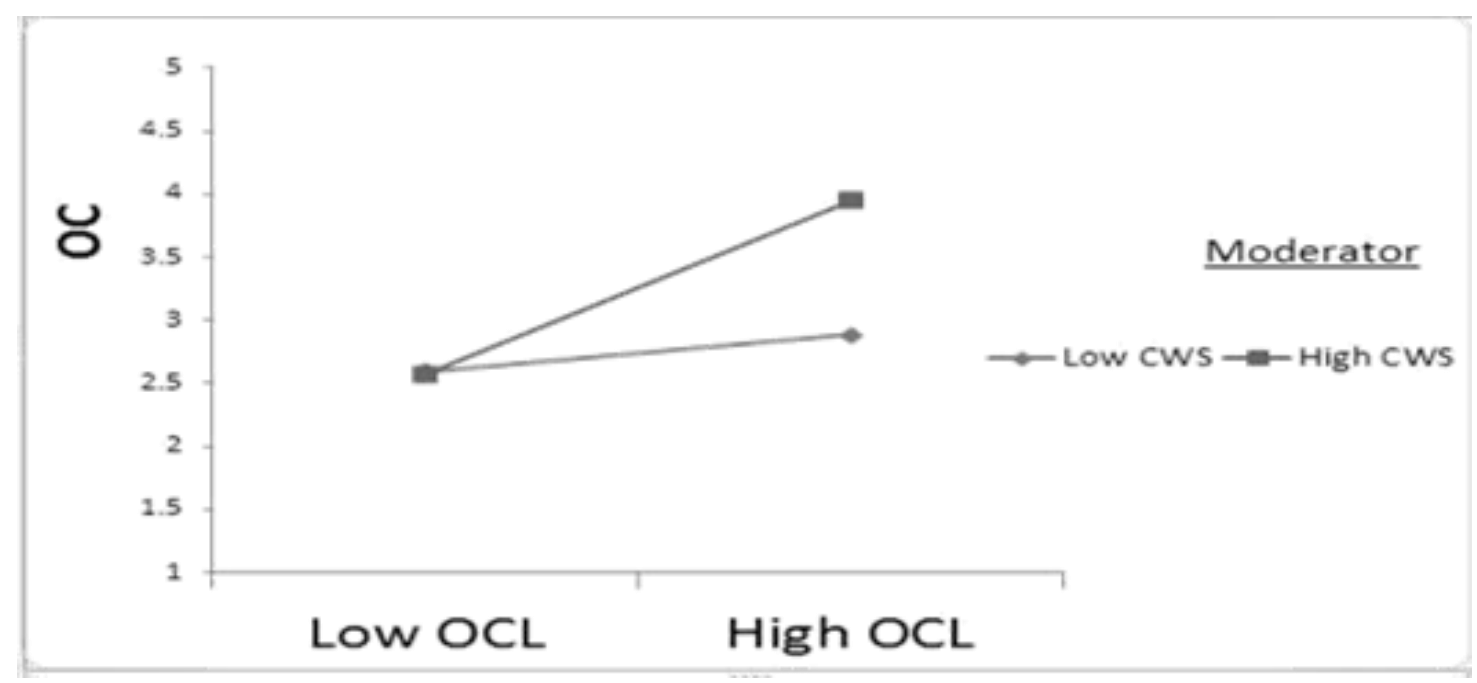

Figure 3: Interaction effect of coworker support on organizational climate and OC.

Furthermore, the r square for OC is 0.42 which suggests that the SS and organizational climate explain 42 percent variance in it.

\section{Discussion}

The core intention of this research was to analysis the impact of SS and organizational climate over the OC of academics of public higher education institutions (HEIs) in Pakistan. The results of the current study suggest an imperative relationship between the SS and the OC. The results are consistent 
with the findings of previous studies. (Ahmad, Kura, Bibi, Khalid, \& Rahman Jaaffar, 2019). This implies that if employees have earned adequate support from supervisors, the employee would exhibit constructive conduct towards their organization in return. Thus, the support of the manager is one of the key factors that affect the commitment of the employee. SET also supports verdicts that, if academic workers receive support from the organization as a result, they feel empowered and increase their degree of commitment to their organization. (Newman et al., 2011).

The results also confirmed existence of imperious link between the organizational climate and commitment. The result of present research study is consistent with Ekvall, Frankenhaeuser and Parr (1996), signifying that good and safe organizational climate have positive effect on OC. The association between organizational climate and commitment at organizations is also explained by SET theory (Blau, 1964), which suggests that when employees are provided with better working climate, they are more committed with the organization. Thus, the outcome showed that when organizations pay proper attention to provide conducive organizational climate, the employee are more committed with the organization. Therefore, the universities and HEC should ensure providing conducive working climate to academic staff in order to enhance their commitment level.

Hypothesis 03 was used to determine whether coworker support moderates the relationship between SS and OC. The empirical outcomes confirm this hypothesis $(\beta=0.413, t=4.606, p<0.00)$. The present study also supports the argument of Zhou \& George, (2001) that Coworker support plays a crucial role in OC, exchanging ideas and delivering coaching practices.. The current study suggests that good friendly relationship between academic staff of higher education institutions in Pakistan can increase higher level employee commitment. Thus it is evident that coworker has the ability to create pleasant or unpleasant surroundings. It is also a proof that a decent and supportive interpersonal relationship of a coworker makes work simpler and joyful enough to improve job satisfaction and employee commitment.

Moreover, the PLS path modeling outcomes shown that the coworker support moderates the association between the organizational climate and OC as shown in Table 3 ( $\beta=0.247, t=2.420, p$ $<$ o.01). The outcome of this study suggests that coworker support moderates the relationship between the independent (organizational climate) and dependent variables (OC) for public universities with high coworker support than for public universities with low coworker support. Therefore, hypothesis 4 was supported. Similarly, this finding is also supported by prior finding such as Babin and Boles, (1996) that coworker support plays major role in development of positive atmosphere at workplace. When employees feel that they were supported by the organization and coworker, they were more committed to the organization. The findings indicated that coworker support play vital role in the development of positive atmosphere at workplace; it improves and supports to increase the OC level of the academic staff particularly in the public sector universities. It may also because of the nature of profession where academic staff interacts with each other frequently, share their knowledge, skill and improve to achieve common organizational goals. The current outcome also displays that when coworkers are supportive and encouraging it affects the OC.

\section{Implications}

The results here lay ground for some theoretical and practical implications related to SS, organizational climate, and commitment. As such it adds to the literature on supervisor support, organizational climate, and commitment. The study was set to find clarity over previous erratic outcome of research and further effort was taken by the current researcher to overcome the limitation 
highlighted in the previous research.

As such, in addition to theoretical contributing to the body of knowledge by investigating and reporting the moderating effects of co-worker support to more clearly elucidate the association between the SS, Organizational climate and commitment at organizations. Research results confirmed the notion that training and growth and the organizational climate are of the utmost importance in increasing the OC of academic staff. This covers the practical standing of the research for policy makers and practitioners. In addition the HR and HEI divisions should also consider the moderating influence of coworker support on the SS association, the organizational climate and the OC. In addition, the HR and HEI divisions may also consider the moderating influence of coworker support on the SS connection, the organizational climate and the employee support. Inside each institution, through employee has colleagues who perform the task at the same level in the organization. Hence, Coworker support is also critical and plays a key role in the commitment of employees.

\section{Limitations and suggestions for future research}

The limitation of the research; first of all, only university staff in KP, Pakistan are the sample in this research. Future study can therefore be extended to other parts of Pakistan. Second, the present analysis considered cross-section methodology. The future research will therefore consider a longitudinal process. Third, only academic staff were respondents to this study and thus non-academic staff may be included in the survey for future studies. Further analysis in other fields, such as manufacturing and service sectors or private universities is also suggested.. And finally, this study employed only two issues (i.e. supervisor support and organizational climate) to study OC. Therefore, more study is necessary to shed light in future on other issues which also effect OC, because OC is attributed to many factors, which is not only limited to supervisor support and organizational climate in higher institutions specially in KPK Pakistan, such as transactional leadership style, transformational leadership styles, promotional opportunities and Assessment of performance.

\section{References}

Abbas, S. G., Yousafzai, M. T., \& Qureshi, M. I. (2015). Coping the Challenge of Change in Academe--Are we really Learning Organizations?. Journal of Managerial Sciences, 9(1).

Abbas, S. G., Yousafzai, M. T., \& Khattak, A. (2015). Internationalization of Universities: Challenges, Threats and Opportunities for Third World Countries. Dialogue (Pakistan), 10(4).

Abdulkareem, R., Chauhan, A., \& Maitama, K. (2015). Relationship between human resource management practices and employee's turnover intention among registered nurses in Nigerian public hospitals: The mediating role of organizational trust. UTM Press, 2, 95- 98.

Abdullah, \& Ramay, I. M. (2012). Antecedents of organizational commitment of banking sector employees in Pakistan. Serbian Journal of Management, 7(1), 89-102.

Ahmad, A., Bibi, P., \& Majid, A. H. A. (2017). The Impact of Training \& Development and Transformational Leadership over Organizational Commitment among Academic Staff in Public Tertiary Institutions: The Buffering Role of Coworker Support. International Journal of Economic Perspectives, 11(1), 417-432.

Ahmad, A., Kura, K. M., Bibi, P., Khalid, N., \& rahman Jaaffar, A. (2019). Effect of Compensation, Training and Development and Manager Support on Employee Commitment: The moderating effect of Co-worker Support. Journal on Innovation and Sustainability. RISUS ISSN 2179-3565, $10(2)$.

Allen, N. J., \& Meyer, J. P. (1997). Commitment in the Workplace: Theory. Research, and Application, Thousand Oaks.

Alvi, S. A., \& Ahmed, S. W. (1987). Assessing Organizational Commitment in a developing country: 
Pakistan, A case Study, Human Relations, 40(5), 267-280.

Bibi, P., Ahmad, A., \& Majid, A. H. (2016). The moderating role of work environment on the relationship between compensation, job security, and employees retention. International Journal of Economic Perspectives, 10(4), 726-738.

Bibi, P., Ahmad, A., \& Majid, A. H. A. (2018). The impact of training and development and supervisor support on employees retention in academic institutions: The moderating role of work environment. Gadjah Mada International Journal of Business, 20(1), 113.

Bibi, P., Ahmad, A., \& Majid, A. H. (2018). HRM Practices and Employee Retention: The Moderating Effect of Work Environment. In Applying Partial Least Squares in Tourism and Hospitality Research (pp. 129-152). Emerald Publishing Limited.

Babin, B. J., \& Boles, J. S. (1996). The effects of perceived co-worker involvement and supervisor support on service provider role stress, performance and job satisfaction. Journal of Retailing, 72(1), 57-76.

Bashir, N., \& Long, C. S. (2015). The relationship between training and organizational commitment among academicians in Malaysia. Journal of Management Development, 34(10), 1227-1245.

Beham, B. (2011). Work-family conflict and organisational citizenship behaviour: Empirical evidence from Spanish employees. Community, Work \& Family, 14(1), 63-80.

Benkhoff, B. (1997). Disentangling organizational commitment. Personnel Review, 26, 114-131.

Billingsley, B.S., \& Cross, L.H. (1992). Predictors of commitment, job satisfaction and intent to stay in teaching: A comparison of general and special educators. Journal of Special Education, 25(4), 453-471.

Blau, P. M. (1964). Exchange and power in social life. New York, NY: Wiley.

Bok, D. (1990). Universities and the Future of America. Durham, NC: Duke University Press.

Boswell, W. R., \& Boudreau, J. W. (2002). Separating the developmental and evaluative performance appraisal uses. Journal of Business and Psychology, 16(3), 391-412.

Chandna, P., \& Krishnan, V. R. (2009). Organizational commitment of information technology professionals: Role of transformational leadership and work-related beliefs. Tecnia Journal of Management Studies, 4(1), 1-13.

Chiaburu, D. S. \& Harrison, D. A. (2008). Do peers make the place? Conceptual synthesis and metaanalysis of coworker effects on perceptions, attitudes, ocbs, and performance. Journal of Applien Psychology. 93(5), 1082-1103.

Covey, S. R. (1991). Principle-centered leadership. New York, NY: Summit Books.

Creswell, J. W., \& Poth, C. N. (2017). Qualitative inquiry and research design: Choosing among five approaches. Sage publications.

Danish, R. Q., Ramzan, S., \& Ahmad, F. (2013). Effect of perceived organizational support and work environment on organizational commitment: Mediating role of self-monitoring.

Advances in Economics and Business, 1(4), 312-317.

DeCotis, T. A. \& Summers, T. P. A. (1987). Path-analysis of a model of the antecedents and consequences of organizational commitment, Human Relations, 40(7), 445-470.

Delery, J. E., \& Doty, D. H. (1996). Modes in theorizing in strategic HRM: tests of universalistic, contingencies, and configurational performance predictions. Academy of Management Journal, 39, 802-835.

Dick, G. (2011). 'The influence of managerial and job variables on organizational commitment in the police'. Public Administration, 89: 2, 557-576.

Ducharme, L. J., \& Martin, J. K. (2000) Unrewarding work, co-worker support and job satisfaction: A test of the buffering hypothesis. Work and Occupations, 27(2), 223-243.

Edgar, F., \& Geare, A. (2005). HRM practice and employee attitudes: Different measures-different results. Personnel Review, 34(5), 534-549. 
Ekvall, G., Frankenhaeuser, M., \& Parr. D. (1996). Change oriented leadership, stress and organizational climate, in Evkall, G. organizational climate for creativity and innovation European Journal of Work and organizational Psychology, 5(1), 105-123.

Fornell, C., \& Larcker, D. F. (1981). Evaluating structural equation models with unobservable variables and measurement error. Journal of Marketing Research 18, 39-50.

Ginsberg, L. (1997). “Training for the long haul”. Computer Shopper. 17, 4

Hair, J. F., Black, W. C., Babin, B. J., \& Anderson, R. E. (2010). Multivariate data analysis (7th ed.). Upper Saddle River, New Jersey: Prentice Hall.

Holtom, B. C., Mitchell, T. R., Lee, T. W., \& Eberly, M. B. (2008). Turnover and retention research: A glance at the past, a closer review of the present, and a venture into the future. The Academy of Management Annals, 2(1), 231-274.

Humphreys, M., \& Hoque, K. (2007). Have the lecturers lost their voice? Involvement and participation in the devolved Further Education sector. The International Journal of Human Resource Management, 18(7), 1199-1213.

Igbaria, M., \& Greenhaus, J.H. (1992). Determinants of MIS employees turnover intensions: A

structured equations model. Communication of the ACM, 35(2): 35 - 49.

Jarzabkowski, L. M. (2003). Teacher collegiality in a remote Australian school. Journal of Research in Rural Education, 18 (3), 139-144.

Karasek, R. A., Triantis, K. P., \& Chaudhry, S. S. (1982). Co-worker and Supervisor Support as Moderators of Associations between Task Characteristics and Mental Strain. Journal of Occupational Behaviour, 3, 181-200.

Khuong, M. N., \& Le Vu, P. (2014). Measuring the effects of drivers organizational commitment through the mediation of job satisfaction: A Study in Ho Chi Minh City, Vietnam. International Journal of Current Research and Academic Review, 2(2), 1-16.

Knapp, M. S. (2003). Professional development as a policy pathway. Review of Research in Education, 27 (1), 109-157.

Krejcie, R. V. \& Morgan, D. W. (1970). Determining sample size for research activities, Educational and Psychological Measurement, 30: 607-610.

Kwon, I. W. G., \& Banks, D. W. (2004). Factors related to the organizational and professional commitment of internal auditors. Managerial Auditing Journal, 19(5), 6o6-622.

London, M. (1993). Relationships between career motivation, empowerment, and support for career development. Journal of Occupational and Organizational Psychology, 66(1), 55-69.

Lam, W., Chen, Z., \& Takeuchi, N. (2009). Perceived human resource management practices and intention to leave of employees: the mediating role of organisational citizenship behaviour in a Sino-Japanese joint venture. International Journal of Human Resource Management, 20(11), 2250-2270.

Lee, Y., Nam, J., Park, D., \& Lee, K.A. (2006). What factors influence customer oriented prosocial behavior of customer-contact employees? Journal of Services Marketing, 20(4),

251-264.

Leonard, L., \& Leonard, P. (2003). The continuing trouble with collaboration: Teachers talk.

Current Issues in Education [On-line], 6 (15).

Lindorff, M. (2001). Are They Lonely at the Top? Social Relationships and Social Support among Australian Managers. Work and Stress, 15, 274-282.

Long, C. S., Ajagbe, M. A., \& Kowang, T. O. (2014). Addressing the Issues on Employees' Turnover Intention in the Perspective of HRM Practices in SME. Procedia-Social and Behavioral Sciences, 129, 99-104.

Mangi, R.A., Soomro, H.J., Ghumro, I., Abidi, A.R,, \& Jalbani, A.A.(2011). A study of job satisfaction among Non PhD faculty in Universities. Australian J. Bus. Manage. Res. 1(7):83-90. 
Meyer, J.P., Paunonen, S.V., Gellaty, I.R., Goffin, R.D., \& Jackson, D.N. (1989). Organizational commitment and job performance: it's the nature of the commitment that counts. Journal of Applied Psychology, 74: 152-156.

Moos, R. H. (1994). Work environment scale manual. Consulting Psychologists Press.

Mowday, R. T., Porter, L. W., \& Steers, R. M. (1982). Employee-Organization Linkages: The

Psychology of Commitment, Absenteeism, and Turnover. New York: Academic Press.

Mowday, R. T., Steers, R., \& Porter, L. W. (1979). The measurement of organizational commitment. Journal of Vocational Behavior, 14, 224-247.

Newman, A., Thanacoody, R. ve Hui, W. (2011), “The Impact of Employee Perceptions of Training on Organizational Commitment and Turnover Intentions: A Study of Multinationals in the Chinese Service Sector", The International Journal of Human Resource Management, 22(8), 1765-1787.

Porter, L.W., Steers, R.M., Mowday, R.T., \& Boulian, P.V. (1974). Organizational Commitment, Job Satisfaction, and Turnover among Psychiatric Technicians. Journal of Applied Psychology, 59, 603-609.

Prowse, P., \& Prowse, J. (2009). The dilemma of performance appraisal. Measuring Business Excellence, 13(4), 69-77.

Rousseau, V., \& Aubé, C. (2010). Social Support at Work and Affective Commitment to the Organization: The Moderating Effect of Job Resource Adequacy and Ambient Conditions. The Journal of Social Psychology, 150(4), 321-340.

Saba, I. (2011). Measuring the job satisfaction level of the academic staff in Bahawalpur Colleges. International Journal of Academic Research in Business and Social Sciences, 1(1), 1-8.

Schuler, R. S. \& MacMillan, I. (1984). Gaining competitive advantage through human resource practices. Human Resource Management, 23(3), 241-256.

Senge, P. (1990). The fifth discipline. New York, NY: Doubleday.

Steers, R.M. (1977), “Antecedents and outcomes of organizational commitment”, Administrative Science Quarterly, Vol. 22, pp. 46-56.

Tan, F. (2008). Linking Career development practices to turnover intention: The mediator of perceived organizational support. Journal of Business and Public Affairs, 2(1), 1-16.

Thomas N. Garavan. (1997). "Interpersonal skills training for quality service interactions” Industrial and Commercial Training. 29 (3) ,70-77.

Tolman, E. C. (1926). A behavioristic theory of ideas. Psychological Review, 33, 352-396.

Tsai, W-C., \& Tai, W-T. (2003). 'Perceived Importance as a Mediator of the Relationship between Training Assignment and Training Motivation'. Personnel Review, 32, 151-163.

Tschannen-Moran, M. (2001). Collaboration and the need for trust. Journal of Educational Administration, 39(4), 308-331.

Vanaki, Z., \& Vagharseyyedin, S. A. (2009). Organizational commitment, work environment conditions, and life satisfaction among Iranian nurses. Nursing \& health sciences, 11(4), 404-409.

Wang, J., Odell, S. J., \& Schwille, S. A. (2008). Effects of teacher induction on beginning teachers' teaching: A critical review of the literature. Journal of Teacher Education, 59(2), 132-152.

Werther, W.B., \& Davis, K. (1996). Human Resource and Personnel Management. 5Th Edition. Boston: McGraw-Hill, 1996. 